\title{
Inflammation and adipose tissue: effects of progressive load training in rats
}

\author{
Fábio S Lira ${ }^{1 *}$, José C Rosa ${ }^{1,5}$, Gustavo D Pimentel ${ }^{1}$, Victor AF Tarini ${ }^{2}$, Ricardo M Arida ${ }^{3}$, Flávio Faloppa ${ }^{2}$, \\ Eduardo S Alves ${ }^{1}$, Cláudia O do Nascimento ${ }^{1}$, Lila M Oyama ${ }^{1}$, Marília Seelaender $^{6}$, Marco T de Mello $^{5}$, \\ Ronaldo VT Santos ${ }^{4,5^{*}}$
}

\begin{abstract}
Introduction: Cytokines (IL-6, IL-10 and TNF- $\alpha$ ) are increased after exhaustive exercise in the rat retroperitoneal (RPAT) and mesenteric adipose tissue (MEAT) pads. On the other hand, these cytokines show decreased expression in these depots in response to a chronic exercise protocol. However, the effect of exercise with overload combined with a short recovery period on pro- and anti-inflammatory cytokine expression is unknown. In the present study, we investigated the regulation of cytokine production in the adipose tissue of rats after an overtraining-inducing exercise protocol.
\end{abstract}

Methods: Male Wistar rats were divided into four groups: Control (C), Trained (Tr), Overtrained (OT) and recovered overtrained (R). Cytokines (IL-6, TNF- $\alpha$ and IL-10) levels and Toll Like Receptor 4 (TLR4), Nuclear Factor kBp65 (NF-kBp65), Hormone Sensitive Lipase (HSL) and, Perilipin protein expression were assessed in the adipose tissue. Furthermore, we analysed plasma lipid profile, insulin, testosterone, corticosterone and endotoxin levels, and liver triacylglycerol, cytokine content, as well as apolipoprotein B (apoB) and TLR4 expression in the liver.

Results: OT and R groups exhibited reduced performance accompanied by lower testosterone and increased corticosterone and endotoxin levels when compared with the control and trained groups. IL-6 and IL-10 protein levels were increased in the adipose tissue of the group allowed to recover, in comparison with all the other studied groups. TLR-4 and NF-kBp65 were increased in this same group when compared with both control and trained groups. The protein expression of HSL was increased and that of Perilipin, decreased in the adipose in R in relation to the control. In addition, we found increased liver and serum TAG, along with reduced apoB protein expression and IL-6 and IL-10 levels in the of R in relation to the control and trained groups.

Conclusion: In conclusion, we have shown that increases in pro-inflammatory cytokines in the adipose tissue after an overtraining protocol may be mediated via TLR-4 and NF-kBp65 signalling, leading to an inflammatory state in this tissue.

\section{Introduction}

The current view of the function of white adipose tissue (WAT) envisages its secretory properties in addition to lipid storage [1]. WAT actively secretes various bioactive peptides, termed "adipokines", which act locally and distally with autocrine, paracrine and endocrine effects [2].

\footnotetext{
* Correspondence: fabioslira@gmail.com; ronaldo.thomatieli@unifesp.br ${ }^{1}$ Department of Physiology of Nutrition, Universidade Federal de São Paulo, São Paulo, Brazil

${ }^{4}$ Department of Bioscience, Universidade Federal de São Paulo, Baixada Santista Campus, São Paulo, Brazil

Full list of author information is available at the end of the article
}

TNF- $\alpha$ is the most-studied cytokine in WAT, and the greatest mRNA expression is found in the adipocyte [3]. This cytokine is involved in metabolic, physiological and immunological regulation in this tissue and plays a pivotal role in the production of several other cytokines (e.g., IL-10) and adipokines in WAT, such as leptin $[4,5]$. For instance, the anti-inflammatory interleukin 10 (IL-10) secreted by human subcutaneous and visceral adipose depots is more expressed in the latter [6]. However, tumor necrosis factor $\alpha$ (TNF- $\alpha$ ), an important proinflammatory cytokine with a major role in the regulation of cellular processes, is secreted in a similar way by
C Biomed Central

(ㄷ) 2010 Lira et al; licensee BioMed Central Ltd. This is an Open Access article distributed under the terms of the Creative Commons Attribution License (http://creativecommons.org/licenses/by/2.0), which permits unrestricted use, distribution, and reproduction in any medium, provided the original work is properly cited. 
the human subcutaneous and visceral adipose depots [7]. The expression of these pro-inflammatory factors depends on the Nuclear factor kB (NF-kB) pathway. Toll like receptor 4 may activate NF-kB, which is a transcription factor and increase the pro-inflammatory response.

In stress-related situations such as exhaustive exercise and cancer cachexia, the adipose tissue shows increased expression of cytokines that act both locally and distally with autocrine, paracrine and endocrine effects $[8,9]$. Acute exhaustive exercise induces a pro-inflammatory response in the adipose tissue, enhancing IL- 6 and TNF- $\alpha$ levels [8]. However, endurance exercise training induces an anti-inflammatory response in the adipose tissue, with increased IL-10 levels [10].

The effect of overload-associated exercise with a short recovery period on pro- and anti-inflammatory cytokines is however unknown. The aim of this study was to examine the effects of an overtraining protocol in the animal model upon the expression of pro- (TNF- $\alpha$ and IL-6) and anti-inflammatory (IL-10) adipokines, toll-like receptor 4 (TLR4) and nuclear factor kappa B (NF-kB) in depot of adipose tissue.

\section{Materials and methods \\ Animals}

Thirty-five Wistar rats, $60 \mathrm{~d}$ old and weighing 200-280 $\mathrm{g}$ were housed under environmentally controlled conditions (7:00-19:00 hr light/dark cycle; $22-24^{\circ} \mathrm{C}$ ) and permitted free access to food and water throughout the experiment. A motorized treadmill (Columbus instruments) with 6 individual lanes without inclination was used. A shock grid at the back of the treadmill provided a mild shock $(2,0 \mathrm{~mA})$ if the rats pace went below the treadmill rate. The animals were familiarized with the apparatus for three days by placing them on a treadmill for $10 \mathrm{~min} /$ day at a speed of 12 meters $/ \mathrm{min}$ at $0 \%$ degree inclination. To provide a measure of trainability, we rated each animal's treadmill performance on a scale of 1-5 according to the following anchors [1, refused to run; 2 , below average runner (sporadic, stop and go, wrong direction); 3 , average runner; 4, above average runner (consistent runner occasionally fell back on the treadmill); 5 , good runner (consistently stayed at the front of the treadmill)] [11]. Animals with a mean rating of 3 or higher $(n=29)$ were included in the exercise groups and those with a mean rating of 1 or $2(n=6)$ were excluded from the experiment. This procedure was used to exclude possible different levels of stress between animals. All experimental protocols using animals were previously approved by the Animal Experimental Ethics Committee from Federal University of São.

\section{Training Protocol}

The rats were subjected to 11 experimental weeks of training, as adapted from Hohl and cols [12], described in Table 1. The experimental week consisted of five consecutive days of training sessions followed by 2 days of recovery.

The physical training program was divided into 3 phases. The first phase, training phase I (T1), consisted of 4 weeks of progressively running speed and time to enhance cardiorespiratory fitness. In training phase II (T2), running intensity and duration at the end of T1 were maintained for 4 weeks to reach adaptation at a balanced running load. In the last 3 weeks of training, the frequency of daily exercise sessions was increased to two (T2x), three (T3x), and four (T4x) times adopting $\mathrm{T} 2$ training load. Thus, the recovery time between training sessions was reduced ( 4,3 , and $2 \mathrm{~h}$, respectively) to induce an imbalance between overload and recovery. All training sessions were performed in the afternoon, with the first session starting at noon.

Five animals were selected for the control group (CT) and twenty- four animals for the trained $(\mathrm{Tr})$ - overtrained (OT) groups and recovered overtrained protocol (R). The animals of the CT were manipulated at the same time of $\mathrm{Tr}$.

\section{Performance Test}

The training protocol $(\mathrm{Tr})$ was evaluated by three performance tests. The first test was performed at the baseline after animal familiarization with the treadmill, the second test was performed at the end of $\mathrm{T} 1$, and the third test performed at the end of T2. The OT protocol was evaluated by three more tests at the end of the ninth 9 (T4), 10 (T5) and 11 week (T6). Thus, two additional tests were applied after the first (R1) and second (R2) recovery week. Animals were sacrificed $24 \mathrm{~h}$ after test T3 $(\mathrm{n}=8 \mathrm{Tr}), \mathrm{T} 6(\mathrm{n}=8 \mathrm{Tr})$ and $\mathrm{R} 2(\mathrm{n}=8 \mathrm{Tr}$ $\mathrm{n}=5 \mathrm{CT}$ ). The testing protocol for determination the maximal effort was as follows. After a warm-up at 12 $\mathrm{m} / \mathrm{min}$ on a $0 \%$ grade for $5 \mathrm{~min}$, treadmill speed was increased $2 \mathrm{~m} . \mathrm{min}-1$ every $3 \mathrm{~min}$ until animals refused to run, which was defined as the time at which the animals could not sustain running speed without touching the shock grid ten times in $1 \mathrm{~min}$. The body weight was also recorded on a digital scale before each performance test. (T0-T2, T2x-T4x, and R1-R2).

\section{Performance Quantification}

We measured the effect of training over time. According to Hohl and cols [12] animal's performance was quantified using a mass dependent model where mechanical work is equivalent to mass $\times$ speed stage $\times n$ of minutes performed at each stage. This procedure permits the rat's performance to be measured through a quantity 
Table 1 Training Protocol

\begin{tabular}{|c|c|c|c|c|c|}
\hline $\begin{array}{l}\text { Experimental } \\
\text { week }\end{array}$ & $\begin{array}{l}\text { Training } \\
\text { phases }\end{array}$ & $\begin{array}{l}\text { Training speed (m. } \\
\left.\min ^{-1}\right)\end{array}$ & $\begin{array}{l}\text { Training time per session } \\
(\text { (min) }\end{array}$ & $\begin{array}{l}\text { Number of daily } \\
\text { sessions }\end{array}$ & $\begin{array}{l}\text { Recovery between training } \\
\text { sessions }\end{array}$ \\
\hline 1 & $\mathrm{~T} 1$ & 15 & 20 & 1 & 24 \\
\hline 2 & $\mathrm{~T} 1$ & 20 & 30 & 1 & 24 \\
\hline 3 & $\mathrm{~T} 1$ & 22.5 & 45 & 1 & 24 \\
\hline 4 & $\mathrm{~T} 1$ & 25 & 60 & 1 & 24 \\
\hline $5-8$ & $\mathrm{~T} 2$ & 25 & 60 & 1 & 24 \\
\hline 9 & $\mathrm{~T} 2 \mathrm{x}$ & 25 & 60 & 2 & 4 \\
\hline 10 & T3x & 25 & 60 & 3 & 3 \\
\hline 11 & $\mathrm{~T} 4 \mathrm{x}$ & 25 & 60 & 4 & 2 \\
\hline
\end{tabular}

that is proportional to the mechanical work as shown by the respective equation

$$
\operatorname{Pr}=\sum \operatorname{Pr} \mathrm{i}=\sum \mathrm{mViTi}=\sum \mathrm{mDi}=\mathrm{mD},
$$

where Pr represents the rat's performance; Pri is the rat's performance in each stage; $\mathrm{m}$ is the body mass; $\mathrm{Vi}$ is the stage velocity; $\mathrm{Ti}$ is the stage running time; $\mathrm{Di}$ is the stage distance; and $\mathrm{D}$ is the total distance covered by expressed kilogram meters (kg.m).

\section{Serum hormone levels}

After a rest period of 24 hours after the last workout session, the animals were killed by decapitation without anesthesia. Immediately after euthanasia blood was collected and serum samples were separated after allowing blood to clot on ice. Serum was stored frozen at $80^{\circ} \mathrm{C}$ for analysis. Serum insulin, testosterone and corticosterone were quantified using enzyme-linked immunosorbent assay (ELISA). For insulin the kit was obtained from Millipore Corp. Bedford, MA, USA and for testosterone and corticosterone from Assay Designs, Inc., Ann Arbor, MI, USA.

\section{Measurement of circulating endotoxin levels}

Serum endotoxin was assayed using a chromogenic limulus amebocyte lysate (LAL) test, which is a quantitative test for gram-negative bacterial endotoxin (Cambrex). Gram-negative bacterial endotoxin catalyzes the activation of a proenzyme in the LAL. The initial rate of activation is directly determined by the concentration of endotoxin. The activated enzyme catalyzes the splitting of p-nitroaniline (pNA) from the colourless substrate Aclle-Glu-Ala-Arg-pNA. The pNA released was measured photometrically at $405-410 \mathrm{~nm}$ following termination of the reaction. The correlation between the absorbance and the endotoxin concentration is linear in the 0.1-1.0 $\mathrm{EU} / \mathrm{ml}$ For the purposes of this study, all samples were run in duplicate within the same plate; therefore, no interassay variability was observed in this study.

To assess recovery of endotoxin within the assay, known concentrations of recombinant endotoxin $(0.25$ and $1.00 \mathrm{EU} / \mathrm{ml}$ ) were added to diluted, serum to determine whether the expected concentration correlated closely with the actual observed value and whether there were any variations due to reaction with serum contents. Lyophilized endotoxin (E. coli origin) was used to generate a standard curve with the chromogenic LAL test kit from Cambrex and produced a corresponding curve in accordance with the manufacturer's instructions.

\section{Lipid profile and liver TAG determination}

Triglycerides and total cholesterol were assessed through commercial enzymatic kits (Labtest ${ }^{\circ}$, São Paulo, Brazil). Plasma glucose concentration was analysed using the enzymatic colorimetric method (Biotécnica, São Paulo, Brazil). Liver TAG content was measured with the method described by Folch et al [13].

\section{Measurement of TNF- $\alpha$, IL-10, IL- 6 protein levels}

Following euthanasia, the epidydimal white adipose tissue and liver were removed, snaped frozen in liquid nitrogen, and stored at $-80^{\circ} \mathrm{C}$. Frozen tissues $(0.1-0.3 \mathrm{~g})$ were homogenised in RIPA buffer $(0.625 \%$ Nonidet P-40, $0.625 \%$ sodium deoxycholate, $6.25 \mathrm{mM}$ sodium phosphate, and $1 \mathrm{mM}$ ethylene-diamine tetraacetic acid at $\mathrm{pH} 7.4$ ) containing $10 \mu \mathrm{g} / \mathrm{ml}$ of a protease inhibitor cocktail (Sigma-Aldrich, St. Louis, Missouri). Homogenates were centrifuged at $12.000 \mathrm{~g}$ for $10 \mathrm{~min}$ at $4{ }^{\circ} \mathrm{C}$, the supernatant was saved, and protein concentration was determined using the Bradford [14] assay (Bio-Rad, Hercules, California) with bovine serum albumin as a reference. Quantitative assessment of TNF-a, IL- 6 and IL-10 proteins was carried out by ELISA (DuoSet ELISA, R\&D Systems, Minneapolis, MN). For the TNF- $\alpha$ (DY510), IL-6 (DY506) and IL-10 (DY522) assays, sensitivity was found to be $5.0 \mathrm{pg} / \mathrm{ml}$ in the range of $31.2-2000 \mathrm{pg} / \mathrm{ml}$. The intra- and inter-assay variability of the TNF- $\alpha$ and IL- 6 kits was $2.7-5.2 \%$ and 4.9-9.5\%, respectively. Assay sensitivity for IL-10 was $10 \mathrm{pg} / \mathrm{ml}$ in the range from 31.2 to $2000 \mathrm{pg} / \mathrm{ml}$. The intraassay variability of the IL-10 kit was $2.0-4.2 \%$, and its interassay variability was $3.3-6.4 \%$. All samples were run as duplicates, and the mean value was reported. 


\section{Protein analysis by Western Blotting}

After euthanasia, the epidydimal white adipose tissue and liver were rapidly removed and homogenized in $1.5 \mathrm{ml}$ extraction buffer (100 mM Trizma, 1\% SDS, $100 \mathrm{mM}$ sodium pyrophosphate, $100 \mathrm{mM}$ sodium fluoride, $10 \mathrm{mM}$ EDTA and $10 \mathrm{mM}$ sodium vanadate) and boiled for $10 \mathrm{~min}$. The extracts were then centrifuged at 12,000 rpm at $4^{\circ} \mathrm{C}$ for $40 \mathrm{~min}$ to remove insoluble material. Protein determination in the supernatants was performed by the Bradford [14] dye method using the Bio-Rad reagent (Bio-Rad Laboratories, Hercules, CA, USA). The proteins were treated with Laemmli sample buffer containing dithiothreitol and boiled for 5 min before loading onto 8\% SDS-PAGE in a Bio-Rad miniature slab gel apparatus. Similar sized aliquots ( $90 \mathrm{~g}$ ) were subjected to SDS-PAGE as described elsewhere [15]. Electrotransfer of proteins from the gel to nitrocellulose was performed for $1 \mathrm{~h}$ at $120 \mathrm{~V}$ (constant) in a Bio-Rad miniature transfer apparatus. Nonspecific protein binding to the nitrocellulose was reduced by preincubation for $1 \mathrm{~h}$ at $22^{\circ} \mathrm{C}$ in blocking buffer (5\% nonfat dry milk, $10 \mathrm{mM}$ Tris, $150 \mathrm{mM} \mathrm{NaCl}$ and $0.02 \%$ Tween 20). The nitrocellulose membranes were incubated overnight at $4^{\circ} \mathrm{C}$ with antibodies against TLR4, NF- $\kappa$ Bp 65 , Perilipin, HSL, apoB and alpha-Tubulin obtained from Santa Cruz Biotechnology (Santa Cruz, CA, USA) diluted in blocking buffer added with $1 \%$ bovine serum album (BSA)in and then washed for $30 \mathrm{~min}$ in blocking buffer without BSA. The blots were subsequently incubated with peroxidase- conjugated secondary antibody for $1 \mathrm{~h}$ and processed for enhanced chemiluminescence to visualize the immunoreactive bands. Band intensity was evaluated by optical densitometry (Scion Image-Release Beta 3b, NIH, USA) of the developed autoradiographs.

\section{Statistical analysis}

All data are expressed as mean \pm standard error (SE). Intergroup comparisons were performed by using the oneway ANOVA test. Post hoc comparison tests between groups were made using the Tukey test. The Student's $t$-test was used to evaluate the statistical significance of differences between means when need. A $P$ value of less than 0.05 was considered statistically significant.

\section{Results}

The crossover analysis of the performance of baseline, trained, overtrained and recovered groups from tests 1 to 8 . We observed that performance increased progressively at test 3 and that adopting a reduced recovery time induced decreased performance in test 4 . In test 5 , we observed no variation of performance, and tests 6-8 showed the progressive reductions in performance characteristic of the overtraining syndrome (data not shown).

Table 2 shows the lipid profile, liver triglyceride content and insulin levels in all groups. Total cholesterol, glucose and insulin levels were not changed among the groups ( $p>0.05)$, but serum triglyceride concentration was increased $(27 \%, \mathrm{p}<0.05)$ by overtraining. Liver TAG was augmented in the overtrained $(60 \%, \mathrm{p}<0.05)$ and recovered $(80 \%, \mathrm{p}<0.05)$ groups when compared with the control group.

Figure 1 shows cytokine expression in the liver. While TNF- $\alpha$ was unchanged, IL- 6 was decreased $(\mathrm{p}<0.05)$ in the recovered group when compared with all groups, and IL-10 protein levels were reduced $(\mathrm{p}<0.05)$ in the recovered group when compared with the control.

Figure 2 shows hepatic apoB (Figure 2a) and TLR-4 (Figure $2 b$ ) protein expression. The overtrained and recovered groups showed diminished apoB protein expression $(\mathrm{p}<0.05)$ compared with the control group. There was no change in TLR-4 among groups.

Figure 3 shows cytokine levels in the adipose tissue. We found that while TNF- $\alpha$ was unchanged, IL- 6 and IL-10 were increased $(\mathrm{p}<0.05)$ in the recovered group, when compared with all other groups.

Figure 4 shows TLR-4 (Figure 4a) and NF- $\kappa$ Bp65 (Figure $4 \mathrm{~b}$ ) protein expression in the adipose tissue. TLR-4 protein expression was reduced $(\mathrm{p}<0.05)$ in the trained group when compared with the control group and increased in the recovered group relative to all other groups. Reduced NF- $\kappa$ Bp 65 protein expression $(\mathrm{p}<0.05)$ was found in the trained group relative to the control and overtrained groups, and the recovered group showed an increase in relation to all other groups.

Figure 5 shows HSL (Figure 5a) and Perilipin (Figure 5b) protein expression in the adipose tissue. HSL was increased in the trained, overtrained and recovered groups (all groups, $\mathrm{p}<0.05$ ), when compared with the control group. The same parameter was reduced in the trained and recovered groups $(\mathrm{p}<0.05)$, when compared with the control and overtrained groups.

Figure 6 illustrates Endotoxin (Figure 6a), Testosterone (Figure 6b), Corticosterone (Figure 6c) levels, and Testosterone/Corticosterone ratio (Figure 6d). Endotoxin was increased in the overtrained group when compared with the control and trained groups $(\mathrm{p}<0.05)$. Testosterone concentration was reduced $(\mathrm{p}<0.05)$ in the recovered group when compared with the control and trained groups. Corticosterone was increased in the overtrained and recovery groups $(\mathrm{p}<0.05)$ when compared with the control group. Testosterone/Corticosterone ratio was decreased $(\mathrm{p}<0.05)$ in the overtrained and recovery groups when compared with the control group. (Additional files 1 and 2).

\section{Discussion}

We have demonstrated that an overtraining protocol in rats promoted increases in both IL- 6 and IL-10 protein concentration in the white adipose tissue and activated 
Table 2 Metabolic profile in all groups

\begin{tabular}{llllll}
\hline Groups & TG $(\mathbf{m g} / \mathbf{d L})$ & TC $(\mathbf{m g} / \mathbf{d L})$ & Glucose $(\mathbf{m g} / \mathbf{d L})$ & Insulin $(\mathbf{n g} / \mathbf{m L})$ & Hepatic TAG $(\mathbf{m g}$ TAG/100 $\mathbf{m g}$ liver) \\
\hline Control & $136.84 \pm 3.7$ & $198.43 \pm 9.5$ & $100.50 \pm 5.4$ & $2.25 \pm 0.4$ & $10.65 \pm 1.2$ \\
Trained & $143.15 \pm 7.0$ & $172.94 \pm 13.7$ & $95.26 \pm 1.7$ & $2.36 \pm 1.1$ & $14.37 \pm 2.4$ \\
Overtrained & $174.73 \pm 7.8^{*}$ & $166.47 \pm 19.2$ & $95.83 \pm 7.3$ & $3.01 \pm 1.0$ & $16.30 \pm 2.5^{*}$ \\
Recovered & $148.77 \pm 11.4$ & $174.90 \pm 1.5$ & $100.75 \pm 0.9$ & $1.49 \pm 0.9$ & $18.48 \pm 3.3^{*}$ \\
\hline
\end{tabular}

Results are expressed as mean value \pm SE. $p<0.05^{*}$, significantly different from control values.

$\mathrm{TG}=$ triglycerides; $\mathrm{TC}=$ total cholesterol;

the TLR4 and NF-kBp65 pathways as well as HSL and Perilipin protein expression. The results also revealed that both IL- 6 and IL-10 concentration was reduced in the liver, accompanied by lower apoB protein expression and resulting TAG accumulation (steatosis). These data were accompanied by reduced performance in exercise and lower testosterone levels, along with increased endotoxin and corticosterone levels in overtrained rats in comparison with control and trained groups.

Toll-like receptors (TLR) are trans-membrane proteins that play an important role in recognizing microbial pathogens and mediating whole body inflammation [16]. They are expressed and highly present in cells of the innate immune system [17]. TLR-4 is also found in various other cell types, including adipocytes, hepatocytes, and myocytes $[18,19]$. TLR-4 may activate NF-kB and increase the pro-inflammatory response. Nuclear factor $\mathrm{kB}(\mathrm{NF}-\mathrm{kB})$ is a transcription factor associated with the expression of various pro-inflammatory factors [20]. When not stimulated, it is found in the cytoplasm connected to its inhibiting protein, inhibitor $\mathrm{kB}$ kinase (IkB). This complex prevents the translocation of NF-kB to the nucleus.

The endotoxemia that occurs after strenuous exercise results in increased circulating LPS and may be another mechanism underlying the elevation in TLR- 4 and NFkBp65 protein expression [21]. TLR-4 has been shown to be important in LPS-mediated responses that activate NFkBp65 via this cascade in the adipocyte [18]. Our results show that there is a increase in TLR-4 and NFkBp65 protein expression in adipose tissue after overload exercise in rats, and which might be associated with higher endotoxin levels.

In the present study, the recovered group exhibited lower testosterone and the recovered and overtrained groups presented higher corticosterone levels than the trained and control groups. The hormones control anabolic/catabolic pathways that can favour (insulin, testosterone) or antagonise (glucocorticoid hormones) [22] anabolism in skeletal muscles and with consequences to

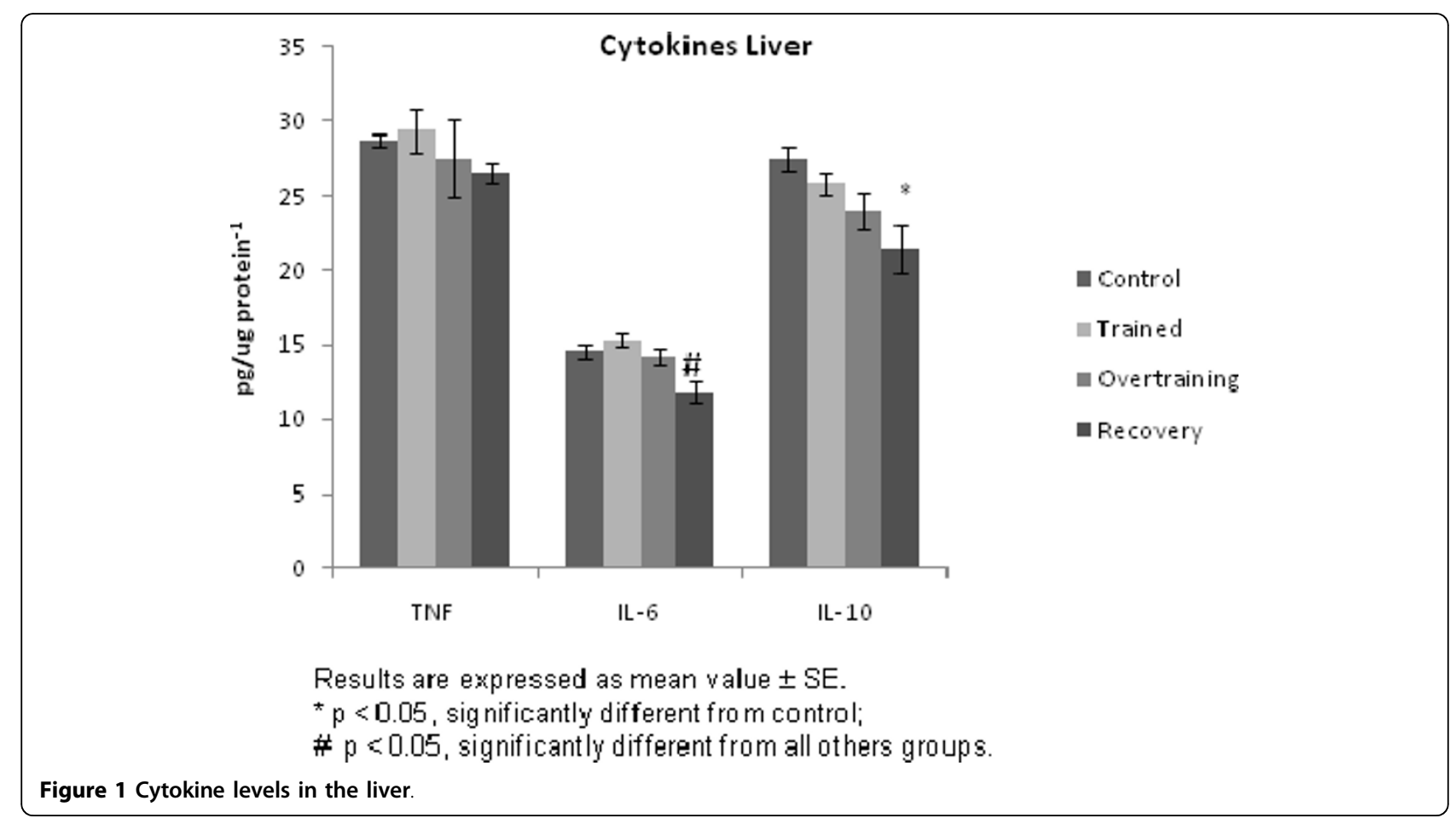



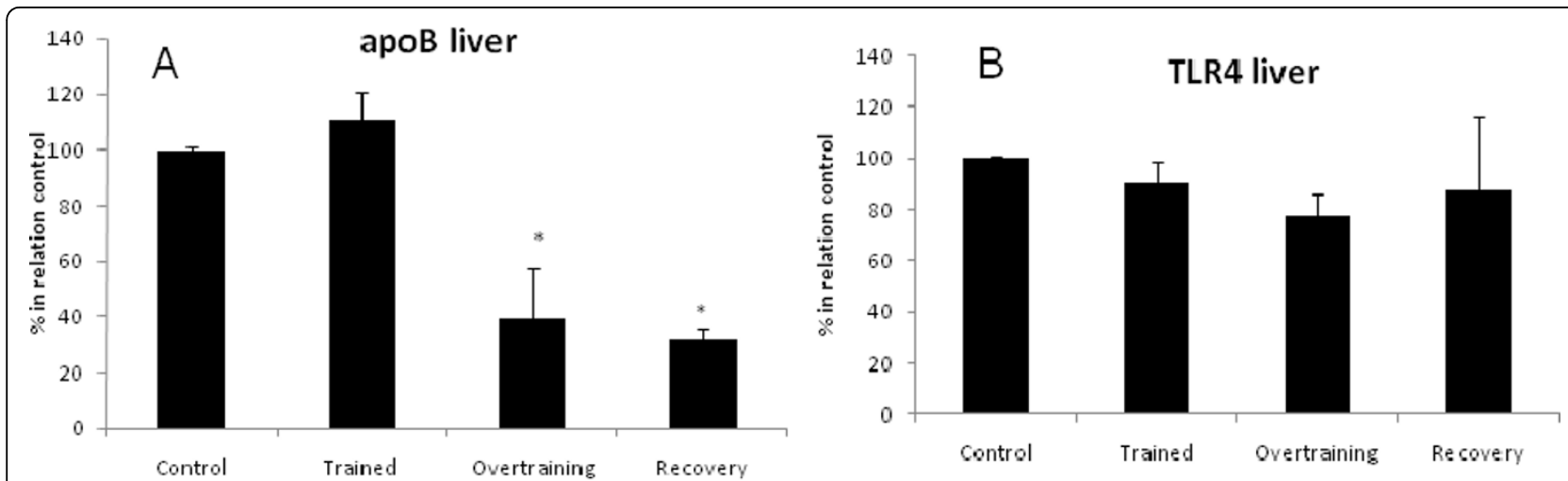

Results are exp ressed as mean value $\pm \mathrm{SE}$.

${ }^{*} p<0.05$, significantly different from control;

Figure 2 Hepatic apoB (2a) and TLR-4 (2b) protein expression

physical performance. In fact, we observed low serum testosterone and increased corticosterone levels and high testosterone/corticosterone ratios after the overtraining protocol, which could have contributed to the observed decrease in performance, and favour a proinflammatory status in adipose tissue.

Exercise represents a physical stress that challenges homeostasis [23]. Therefore, a single bout of exercise is a mild physical stressor that exerts an array of effects on immune parameters $[24,25]$. The body reacts to physical activity as it does during an acute, subclinical inflammatory response to a perceived pathological insult $[26,27]$.
Previous studies have shown that acute exhaustive exercise induces a pro-inflammatory response in the adipose tissue, with elevated IL- 6 and TNF- $\alpha$ levels. This increase can contribute to lipolysis and the release of fatty acids, as energy supply for muscle and other tissues immediately after exercise [8]. However, endurance exercise programs induce an anti-inflammatory response in the adipose tissue and increase IL-10 levels, leading to a protective effect [10]. Many studies [28-32] have demonstrated the benefits of aerobic training, induced by the anti-inflammatory state induced in obese rats and human models. Bradley et al [30] related that voluntary exercise

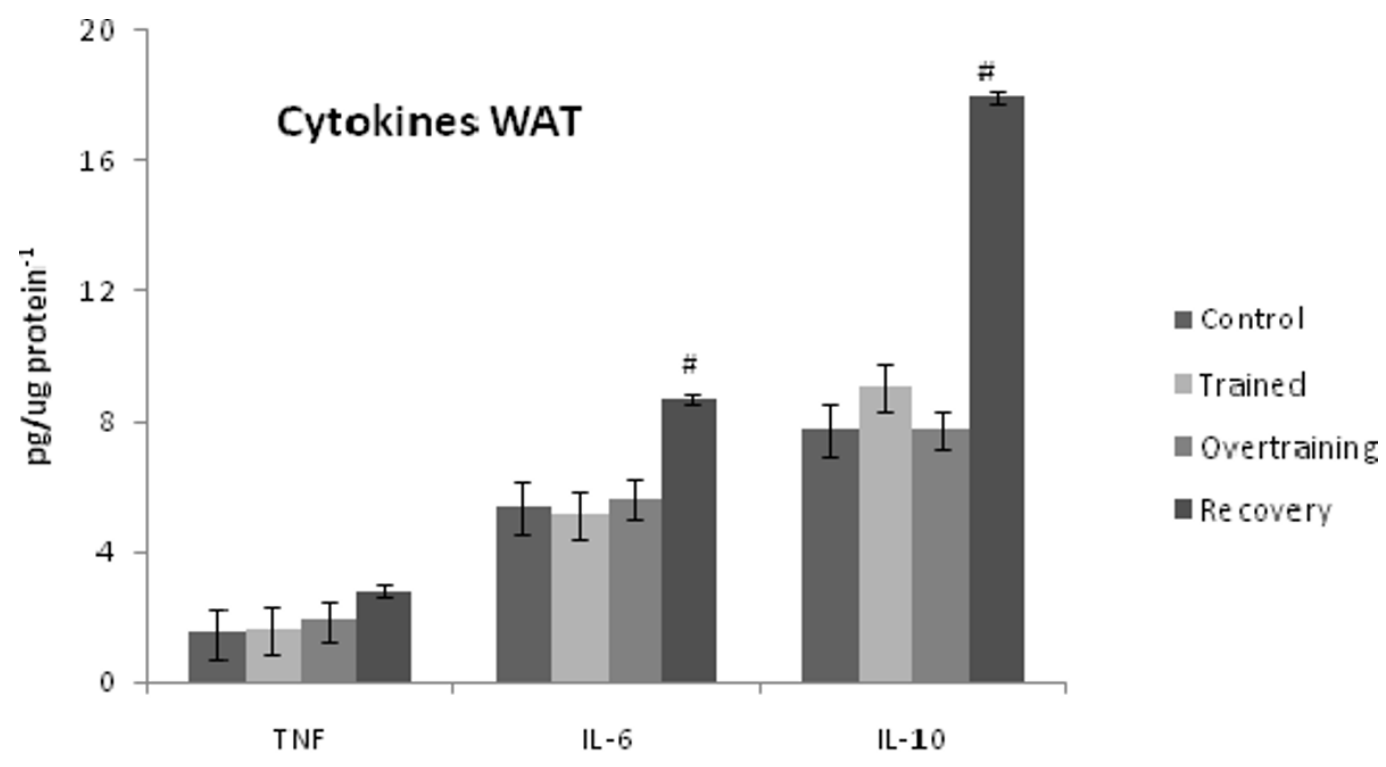

Results are expressed as mean value \pm SE. \# $<<0.05$, significantly different from all others groups.

Figure 3 Cytokine levels in the adipose tissue. 


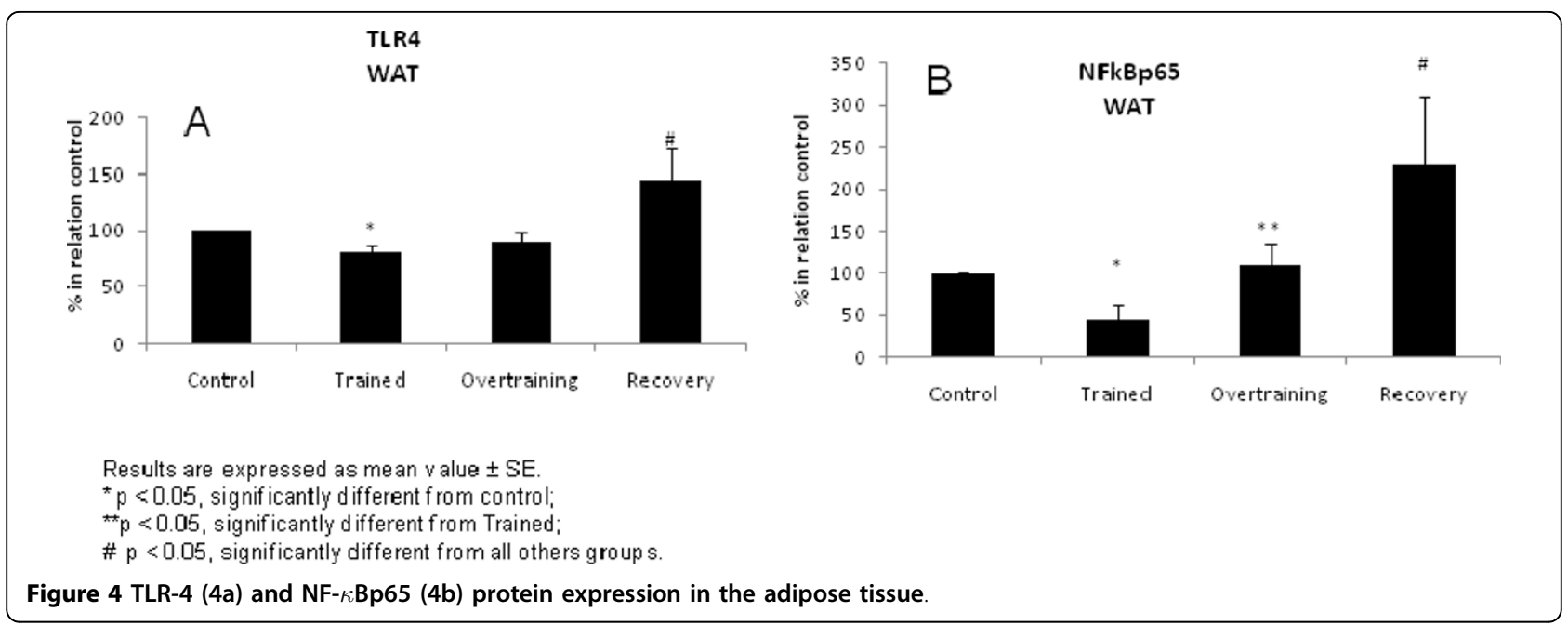

in diet-induced obese mice reduced adiposity despite continued consumption of a high fat diet. In addition, exercise normalised insulin sensitivity and decreased adipose tissue inflammation (reduced IKK- $\beta$ gene expression) in these animals. These results corroborate the present study, in which pro-inflammatory cytokines were reduced in the adipose tissue of the trained group.

Prolonged periods of severe training and short recovery time lead subjects to what is often called the "overtraining syndrome", which is characterized by declining performance despite an extended rest period, which is accompanied by physiological, biochemical, immunological, and psychological symptoms [33-35]. The protocol of overtraining presently adopted was able to induce the same modifications such as reduced performance found by others [12,33-35].

Several studies have explored the immune, endocrine, and psychological systems in animal and human models, with the aim of establishing key markers for the prognosis of the overtraining syndrome. The basis of Smith's hypothesis is that excessive training (high-volume/intensity training) with insufficient rest or recovery causes repetitive tissue trauma, resulting in the acute phase response and then, without adequate recovery, chronic inflammation. This state would be associated with "elevated levels of circulating cytokines (IL-1 $\beta$, TNF- $\alpha$, and/ or IL-6), which would interact with various systems of the body and which, it will be argued, may account for most of the signs and the symptoms that previously have been associated with overtraining" [36].

There is no data in the literature about the effect of the overtraining syndrome upon cytokine production by rat adipose tissue. We show for the first time that adipose tissue contributes to cytokine production in this syndrome and that the TLR4 and NF-kBp65 pathways are involved.

In addition, we observed increased HSL in the trained, overtrained and recovered groups and decreased perilipin protein expression in the adipose tissue of the trained and recovered groups. In part, these results may explain the increase in plasma TAG, indicating exacerbation of

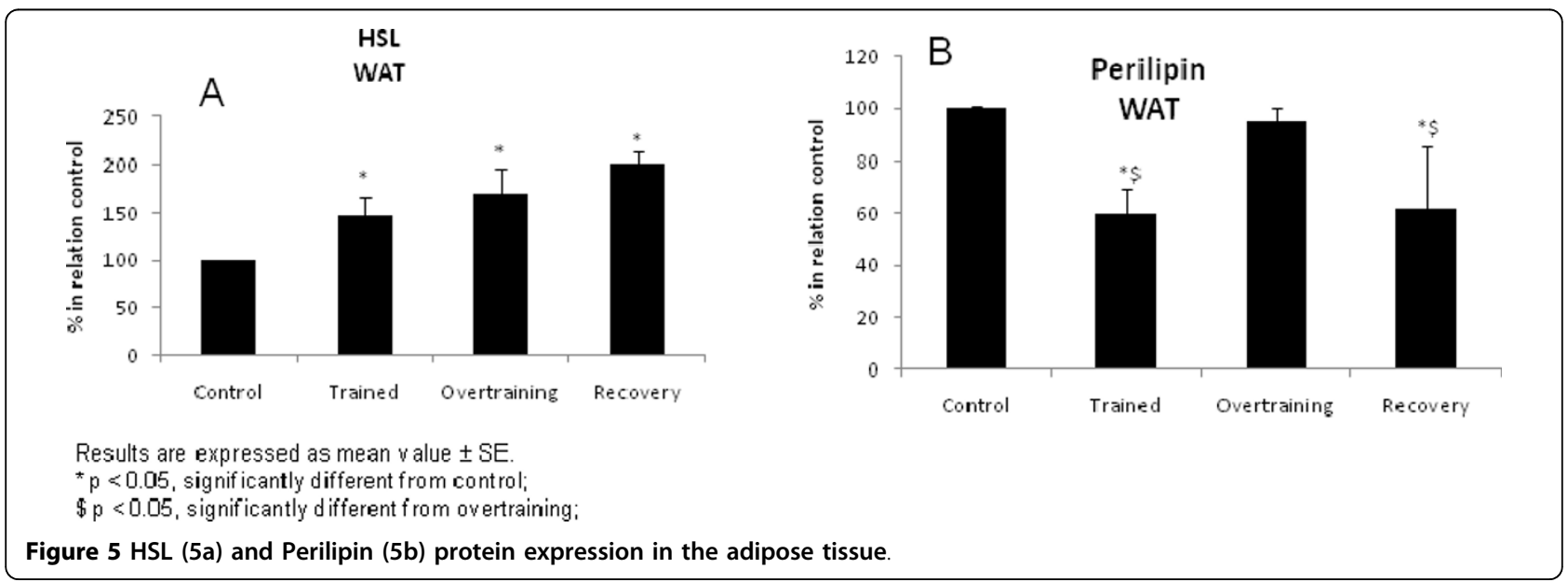




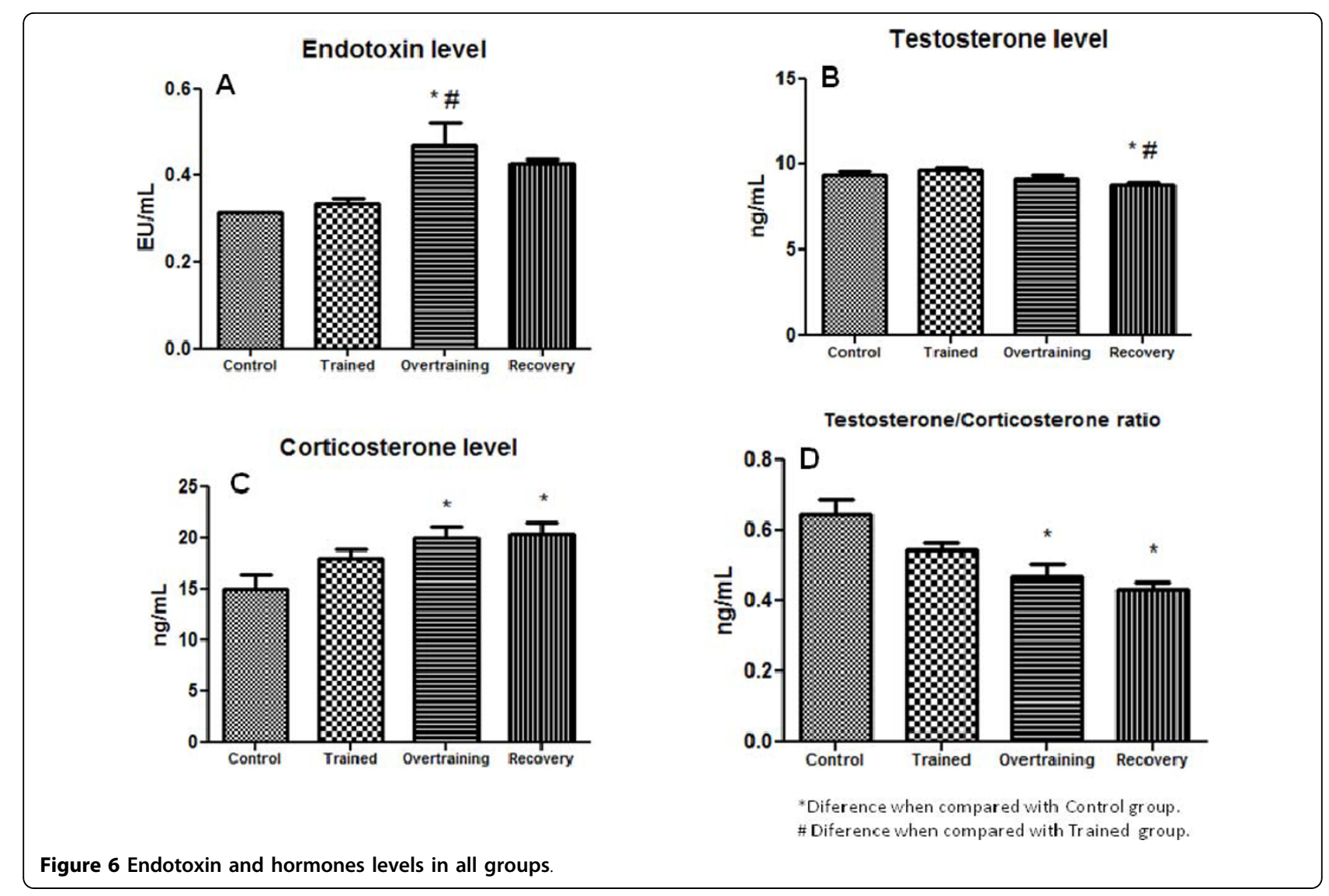

adipose tissue lipolysis in the overtraining protocol. In fact, cytokines such as IL-6 increase lipolysis, decrease lipoprotein lipase activity and increase the mobilization of fatty acids in adipose tissue [8].

Only a small number of studies examined the effect of exercise training on perilipin expression $[37,38]$. Chapados et al [37] demonstrated that chronic moderate exercise ( 8 weeks of training) did not alter perilipin protein expression in the mesenteric adipose tissue after 8 weeks of high-fat feeding. Wohlers and Spangenburg [38] observed that perilipin protein content in mesenteric adipose tissue did not change in exercised mice.

Marked differences in gene expression among depots are reported both for rodents [39] and humans [40], and protein secretion is also heterogeneous [41]. In the present study, we demonstrated that perilipin protein expression in epidydymal adipose tissue was reduced in the trained group. However, the recovery overtrained group also showed reduced perilipin protein expression. This data may also be related to increased lipolysis and consequential contributions to increased TAG levels. Furthermore, increased plasma TAG was accompanied by reduced apoB protein expression in the liver, possibly inducing hepatic steatosis, leading the organism to chronic disease.
Taken together, our results suggest that the increase in cytokine concentration and augmented TLR-4 and NF-kBp65 protein expression induced by overtraining in the epidydymal adipose tissue may lead to a shift toward increased inflammation. Thus, recovery time from exercise training is particularly essential for the prevention of pathological conditions of chronic inflammation. The present study was the first to document the effects of an overtraining protocol on inflammatory and lipolytic status in adipose tissue in rats.

\section{Additional material}

Additional file 1: White Adipose Tissue. Western blot analysis. Representative blots of three independent experiments are shown. Additional file 2: Liver. Western blot analysis. Representative blots of three independent experiments are shown.

\section{Conflicts of interests}

The authors declare that they have no competing interests.

\section{Authors' contributions}

FSL, JCR, GDP, VAFT, RMA, FF, ESA, CON, LMO, MS, MTM and RVTS participed the sample collected, assess samples, design of the study and performed the statistical analysis, and writing of paper. All authors read and approved the final manuscript 


\section{Acknowledgements}

We would like to thank funding sources: 2008/03533-1 from the FAPESP.

\section{Author details}

'Department of Physiology of Nutrition, Universidade Federal de São Paulo, São Paulo, Brazil. 2Department of Orthopaedics and Traumatology, Universidade Federal de São Paulo, São Paulo, Brazil. ${ }^{3}$ Department of Physiology, Universidade Federal de São Paulo (UNIFESP), São Paulo, SP, Brazil. ${ }^{4}$ Department of Bioscience, Universidade Federal de São Paulo, Baixada Santista Campus, São Paulo, Brazil. ${ }^{5}$ Department of Psychobiology, Universidade Federal de São Paulo - UNIFESP, São Paulo, Brazil. ${ }^{6}$ Cancer Metabolism Research Group, Institute of Biomedical Sciences, University of São Paulo, São Paulo, Brazil.

Received: 2 September 2010 Accepted: 4 October 2010

Published: 4 October 2010

\section{References}

1. Cinti S: The adipose organ. Prostaglandins Leukot Essent Fatty Acids 2005, 73:9-15

2. Pond C: Physiological specialisation of adipose tissue. Prog Lipid Res 1999, 38:225-48.

3. Montague CT: Adipose depot-specific effects of PPAR gamma agonists: a consequence of differential expression of PPAR gamma in adipose tissue depots? Diabetes Obes Metab 2002, 4(6):356-61.

4. Coppack S: Pro-inflammatory cytokines and adipose tissue. Proc Nutr Soc 2001, 60:349-356.

5. Trayhurn P, Wood IS: Signalling role of adipose tissue: adipokines and inflammation in obesity. Biochem Soc Trans 2005, 33:1078-1081.

6. Juge-Aubry $C$, Henrichot $E$, Meier $C$ : Adipose tissue: a regulator of inflammation. Best Pract Res Clin Endocrinol Metab 2005, 19:547-566

7. Cawthorn WP, Sethi JK: TNF-alpha and adipocyte biology. FEBS Lett 2008, 582:117-31.

8. Rosa Neto JC, Lira FS, Oyama LM, Zanchi NE, Yamashita AS, Batista ML, Oller do Nascimento CM, Seelaender M: Exhaustive exercise causes an antiinflammatory effect in skeletal muscle and a pro-inflammatory effect in adipose tissue in rats. Eur J Appl Physiol 2009, 106(5):697-704.

9. Lira FS, Rosa JC, Zanchi NE, Yamashita AS, Lopes RD, Lopes AC, Batista ML Jr, Seelaender M: Regulation of inflammation in the adipose tissue in cancer cachexia: effect of exercise. Cell Biochem Funct 2009, 27(2):71-5, Review.

10. Lira FS, Rosa JC, Yamashita AS, Koyama CH, Batista ML, Seelaender M: Endurance training induces depot-specific changes in IL-10/TNF-alpha ratio in rat adipose tissue. Cytokine 2009, 45(2):80-5.

11. Dishman RK, Armstrong RB, Delp MD, Graham RE, Dunn AL: Open-field behavior is not related to treadmill performance in exercising rats. Physiol Behav 1988, 43(5):541-6.

12. Hohl R, Ferraresso RL, De Oliveira RB, Lucco R, Brenzikofer R, De Macedo DV: Development and characterization of an overtraining animal model. Med Sci Sports Exerc 2009, 41(5):1155-63.

13. Folch J, Lees M, Sloane Stanley GH: A simple method for the isolation and purification of total lipides from animal tissues. J Biol Chem 1957, 226:497-509.

14. Bradford MM: A rapid and sensitive method for the quantitation of microgram quantities of protein utilizing the principle of protein-dye binding. Anal Biochem 1976, 7:248-54.

15. Carvalho CR, Thirone AC, Gontijo JA, Velloso LA, Saad MJ: Effect of captopril losartan, and bradykinin on early steps of insulin action. Diabetes 1997, 46:1950-1957.

16. Gleeson M, McFarlin B, Flynn M: Exercise and Toll-like receptors. Exerc Immunol Rev 2006, 12:34-53.

17. Muzio M, Mantovani A: Toll-like receptors. Microbes Infect 2000, 2:251-5.

18. Lin Y, Lee H, Berg AH, Lisanti MP, Shapiro L, Scherer PE: The lipopolysaccharide-activated toll-like receptor (TLR)-4 induces synthesis of the closely related receptor TLR-2 in adipocytes. J Biol Chem 2000, 275:24255-63.

19. Lang CH, Silvis C, Deshpande N, Nystrom G, Frost RA: Endotoxin stimulates in vivo expression of inflammatory cytokines tumor necrosis factor alpha, interleukin-1 beta, -6, and high-mobility-group protein-1 in skeletal muscle. Shock 2003, 19:538-46.
20. Kanayama A, Seth RB, Sun L, Ea CK, Hong M, Shaito A, Chiu YH, Deng L, Chen ZJ: TAB2 and TAB3 activate the NF-kappaB pathway through binding to polyubiquitin chains. Mol Cell 2004, 15:535-48.

21. Bosenberg AT, Brock-Utne JG, Gaffin SL, Wells MT, Blake GT: Strenuous exercise causes systemic endotoxemia. J Appl Physiol 1988, 65:106-8.

22. Zanchi NE, Filho MA, Felitti V, Nicastro H, Lorenzeti FM, Lancha AH Jr: Glucocorticoids: extensive physiological actions modulated through multiple mechanisms of gene regulation. I Cell Physiol 2010, 224:311-5

23. Mastorakos G, Pavlatou M: Exercise as a stress model and the interplay between the hypothalamus-pituitary-adrenal and the hypothalamuspituitary-thyroid axes. Horm Metab Res 2005, 37:577-84, Review.

24. Sprenger $H$, Jacobs C, Nain M, Gressner AM, Prinz H, Wesemann W, Gemsa D: Enhanced release of cytokines, interleukin-2 receptors, and neopterin after long-distance running. Clin Immunol Immunopathol 1992, 63:188-95

25. Schulz KH, Gold SM, Witte J, Bartsch K, Lang UE, Hellweg R, Reer R, Braumann KM, Heesen C: Impact of aerobic training on immuneendocrine parameters, neurotrophic factors, quality of life and coordinative function in multiple sclerosis. J Neurol Sci 2004, 225:11-8.

26. Bury TB, Louis R, Radermecker MF, Pirnay F: Blood mononuclear cells mobilization and cytokines secretion during prolonged exercises. Int $J$ Sports Med 1996, 17:156-60.

27. Camus G, Nys M, Poortmans JR, Venneman I, Monfils T, Deby-Dupont G, Juchmès-Ferir A, Deby C, Lamy M, Duchateau J: Endotoxaemia, production of tumour necrosis factor alpha and polymorphonuclear neutrophil activation following strenuous exercise in humans. Eur J Appl Physiol Occup Physiol 1998, 79:62-8.

28. de Lemos ET, Reis F, Baptista S, Pinto R, Sepodes B, Vala H, Rocha-Pereira P, Silva AS, Teixeira F: Exercise training is associated with improved levels of C-reactive protein and adiponectin in ZDF(type 2) diabetic rats. Med Sci Monit 2007, 13:BR168-74.

29. Ben Ounis O, Elloumi M, Ben Chiekh I, Zbidi A, Amri M, Lac G, Tabka Z: Effects of two-month physical-endurance and diet-restriction programmers on lipid profiles and insulin resistance in obese adolescent boys. Diabetes Metab 2008, 34:595-600.

30. Bradley RL, Jeon JY, Liu FF, Maratos-Flier E: Voluntary exercise improves insulin sensitivity and adipose tissue inflammation in diet-induced obese mice. Am J Physiol Endocrinol Metab 2008, 295:E586-94.

31. Lira FS, Rosa JC, Dos Santos RV, Venancio DP, Carnier J, Sanches PD, do Nascimento CM, de Piano A, Tock L, Tufik S, de Mello MT, Dâmaso AR, Oyama LM: Visceral fat decreased by long-term interdisciplinary lifestyle therapy correlated positively with interleukin-6 and tumor necrosis factor-alpha and negatively with adiponectin levels in obese adolescents. Metabolism 2010.

32. Beavers KM, Brinkley TE, Nicklas BJ: Effect of exercise training on chronic inflammation. Clin Chim Acta 2010.

33. Margonis K, Fatouros IG, Jamurtas AZ, Nikolaidis MG, Douroudos I, Chatzinikolaou A, Mitrakou A, Mastorakos G, Papassotiriou I, Taxildaris K, Kouretas D: Oxidative stress biomarkers responses to physical overtraining: implications for diagnosis. Free Radic Biol Med 2007, 43:901-10.

34. Main LC, Dawson B, Grove JR, Landers GJ, Goodman C: Impact of training on changes in perceived stress and cytokine production. Res Sports Med 2009, 17:121-32

35. Caperuto EC, dos Santos RV, Mello MT, Costa Rosa LF: Effect of endurance training on hypothalamic serotonin concentration and performance. Clin Exp Pharmacol Physiol 2009, 36:189-91.

36. Smith LL: Tissue trauma: the underlying cause of overtraining syndrome? J Strength Cond Res 2004, 18:185-93.

37. Chapados N, Collin P, Imbeault P, Corriveau P, Lavoie JM: Exercise training decreases in vitro stimulated lipolysis in a visceral (mesenteric) but not in the retroperitoneal fat depot of high-fat-fed rats. Br J Nutr 2008, 100:518-25.

38. Wohlers LM, Spangenburg EE: 17beta-estradiol supplementation attenuates ovariectomy-induced increases in ATGL signaling and reduced perilipin expression in visceral adipose tissue. J Cell Biochem 2010.

39. Gesta S, Blüher M, Yamamoto Y, Norris AW, Berndt J, Kralisch S, Boucher J, Lewis C, Kahn CR: Evidence for a role of developmental genes in the origin of obesity and body fat distribution. Proc Natl Acad Sci USA 2006, 103:6676-81 
40. Vohl MC, Sladek R, Robitaille J, Gurd S, Marceau P, Richard D, Hudson TJ, Tchernof A: A survey of genes differentially expressed in subcutaneous and visceral adipose tissue in men. Obes Res 2004, 12:1217-22.

41. Lafontan M, Berlan M: Do regional differences in adipocyte biology provide new pathophysiological insights? Trends Pharmacol Sci 2003, 24:276-83, Review.

\section{doi:10.1186/1476-511X-9-109}

Cite this article as: Lira et al:: Inflammation and adipose tissue: effects

of progressive load training in rats. Lipids in Health and Disease 2010 9:109.

Submit your next manuscript to BioMed Central and take full advantage of:

- Convenient online submission

- Thorough peer review

- No space constraints or color figure charges

- Immediate publication on acceptance

- Inclusion in PubMed, CAS, Scopus and Google Scholar

- Research which is freely available for redistribution 